\title{
Balarāma of Boro: a Unique Specimen of Bengal Sculpture
}

\author{
Sanjay Sen Gupta ${ }^{1}$
}

The folk-tribal tradition of Bengal sculpture, unlike the hieratic genre, has always remained virile without any promotion from the elite class of the society or the royal state. Hence it had to limit itself, while making divine images, mostly within cheaper mediums like clay and natural pigment. Lavish exploration of wood, stone and metal could only be done by the patronized artists of hieratic genre. However, things started to change - suddenly and with immediate effect following the Islamic invasion in early-thirteenth century AD. ${ }^{1}$

Bakhtiyar Khalji, the Turk military general of Qutb-ud-din Aybak, defeated King Lakșmana Sena and founded the Islamic rule at Lakshmanavati or Gaur. ${ }^{2}$ The kingdom became known as the Sultanate of Bengal - being ruled at regular intervals from Delhi. ${ }^{3}$ Hindu political identity thus got limited to mere Chieftainships and Baronships under the new rulers.

The renewed circumstances changed the royal religion, whose patrons were firmly against all sorts of image-worship. They withdrew and thus stopped the funding of five-hundred odd years - resulting into several works being left in the midway. ${ }^{4}$ The highly-skilled artists of PālaSena idiom were appointed in carving royal furniture and accessories, ${ }^{5}$ while many of them took refuge to the neighboring courts Hindu kings. ${ }^{6}$ Worshipping of idols became a secret activity in Bengal and investments were stopped on large-scale quality works. ${ }^{7}$ Quick use of clay and natural pigment became the most suitable alternative - even for the making of hieratic deities.

In this way, thirteenth to fifteenth century $\mathrm{AD}$ constituted an era of acute turmoil ${ }^{8}$ in Bengal - be it in politics, economy, society or culture. ${ }^{9}$ It observed a silent period in art, as specimens assignable to this time-span could hardly be traced. However, the age-old tradition of making wooden idols sustained its demand, while their royal patrons were replaced by local chieftains and Zamindars. Even the poor common folk began to take initiatives for raising funds to install the images of their beloved deities.

It was during this major shift of paradigm, when a massive wooden Balarāma was installed - as the local deity of rain and harvest - in a small village called Boro, PS Raina, in the district of Burdwan, West Bengal. Both in terms of history and aesthetics, it was one of the earliest attempts by the folk-tribal artisans of Bengal to deal with an iconography of the hieratic genre.

\section{Development of the Iconography:}

Lord Balarāma in Indian mythology is known as the elder brother of Krṣna or Vāsudeva-Kṛ̣na. He was described in Mahābhārata as a famous warrior, an expert in agriculture and the mace-fighting teacher of Duryodhana ${ }^{10}$ and Bhïma. ${ }^{11}$ Even after being a kṣatriya ${ }^{12}$ and famous, as Bala, for his

${ }^{1}$ Sanjay Sen Gupta is Assistant Professor (Fine Arts) at School of Fine Arts, Amity University, Kolkata, India. He did PhD (Fine Arts) in Visual Arts from the University of Calcutta (Government College of Art E Craft, Kolkata), India, 2014. Email: sanjaysg1974@gmail.com 
strength and might - he refused to take part in the great war of Kuruksetra. He rather preferred to offer delight to the world and hence was called Räma. He was considered as one of the Daśāvatāra ${ }^{13}$ of Lord Viṣnu, ${ }^{14}$ the most popular iconography of later-Brahmanic Trinity. ${ }^{15}$

In several old scriptures, where the myth of their birth has been recorded, name of Balarāma appears before that of Vāsudeva. In Viṣnu Purāna ${ }^{16}$ the two brothers - white and black have been described as incarnations of Viṣnu. Both were sons of Vasudeva and Devakī, but Balarāma was pulled out of his mother's womb and transferred to that of Rohinī. For this reason, he was also known as Sankarșaṇa. ${ }^{17}$

This Sankarșana was a man-god and an important figure in Bhāgavata, which was an extremely old cult of Viṣu-worshippers. ${ }^{18}$ According to the scriptures, he was associated with his younger brother Vāsudeva-Krșna, nephews Pradyumna ${ }^{19}$ and Sämba, ${ }^{20}$ along with the grandson Aniruddha. ${ }^{21}$ Together they were deified and famously known as the holy Pañca-vìra of Vṛṣni clan. Later on, Sāmba got eliminated and the concept of Vìra was changed into vyūha. ${ }^{23}$ The rest four, however, came to be regarded as Ācārya Caturvyūha ${ }^{24}$ - the four major aspects of Parā-Vāsudeva incorporating Väsudeva as the central icon. ${ }^{25}$

The cult of Balarāma, since the earliest stage of its development, was closely connected with Ananta-Näga - the eternal serpent - of which he is considered to be another incarnation. His earliest known images were based on Nàga-figures, as found in the Kushana triad-sculptures of Visākha/Vāsuki-Devasenā-Skanda. ${ }^{26}$ This Viśákha or Vāsuki is known to be the chief of serpents and a submissive devotee of Lord Siva. His relation with Balarāma has elaborately been narrated in early texts like Harivamśa. ${ }^{27}$ The divine agriculturist, thus being connected to the wandering god, was naturally inclined and addicted to wine. In some of his earliest images he holds a wine cup; while many of the later renderings expressed his intoxication in the drooping eyes. However, like the Boro-Balarāma mentioned above, wine pot became a customary attribute to this deity in the early-part of the medieval period.

\section{Balarāma in Indian Sculpture:}

The earliest depiction of Balarāma or Sañkarșana could be traced in a BC 185 coin of Indo-Greek ruler Agathokles (see fig 1), found from Ai-Khanum of Afghanistan. ${ }^{28}$ A stone-sculpture of the Kushana period $^{29}$ at the Government Museum, Mathura ${ }^{30}$ and another of first century BC at The State Museum, Lucknow - both in Uttar Pradesh - could also be referred to in this regard. In both specimens, the Lord is depicted as standing under a seven-headed Sarpa-chatra or snake hood (see fig 2).

Later on, the Kushana-icon of Viśākha/Vāsuki-Devasenā-Skanda (mentioned above) was derived into the triad of Balarāma-Ekanamśá-Krșna, earliest of which is a second-third century specimen kept in The National Museum of Pakistan, Karachi. Here Viśákha or Vāsuki got transformed into Balarāma, whose posture with Musala ${ }^{31}$ was recorded afterwards in the sixthcentury text of Vrhat Samhita..$^{32}$ Independent depictions of the Lord belonging to the Gupta ${ }^{33}$ and post-Gupta era could also be traced in various Museums and temples of Madhya Pradesh, ${ }^{34}$ Bihar $^{35}$ and Rajasthan ${ }^{36}$ in India, Rajshahi ${ }^{37}$ and Paharpur ${ }^{38}$ in Bangladesh. Among these, an eighthcentury stone-sculpture from Paharpur shows Balarāma under a six-hooded canopy (see fig 3) surprisingly less than the earlier specimens. The deity, however, is manifested with four arms, as described in Agni Purāna, ${ }^{39}$ which has also been followed in the renderings of $\operatorname{tenth}^{40}$ and eleventh centuries. $^{41}$ 


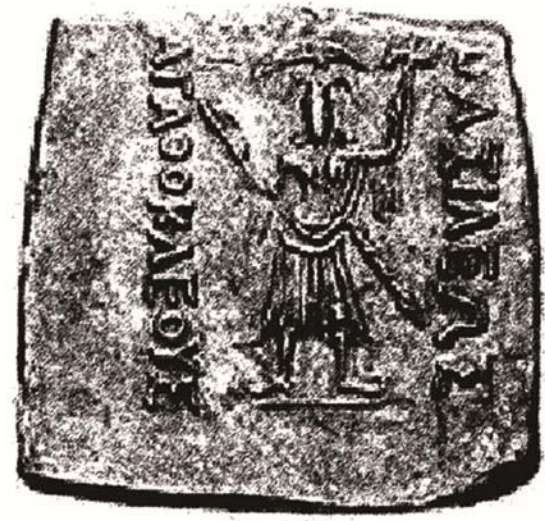

fig 1. Balarāma in the coin of Agathokles, dated BC 185 , found from Ai-Khanum of Afghanistan.

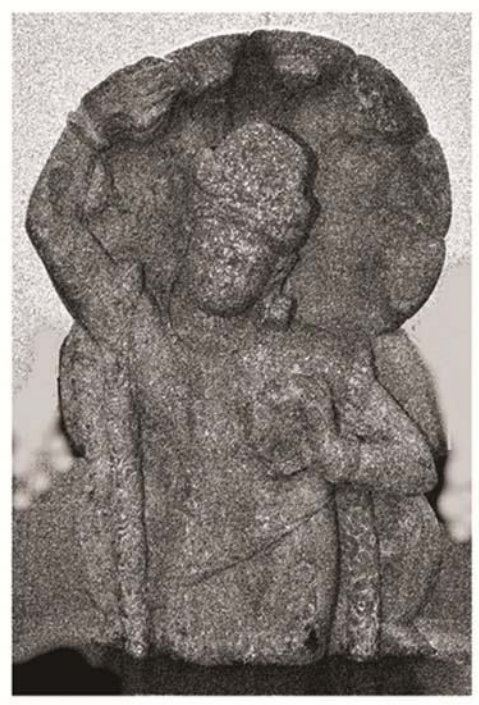

fig 2. Balarāma standing under a seven-headed Sarpa-chatra - a stone-sculpture of Kushana period; now at Government Museum, Mathura (Acc. No: oo-C-15).

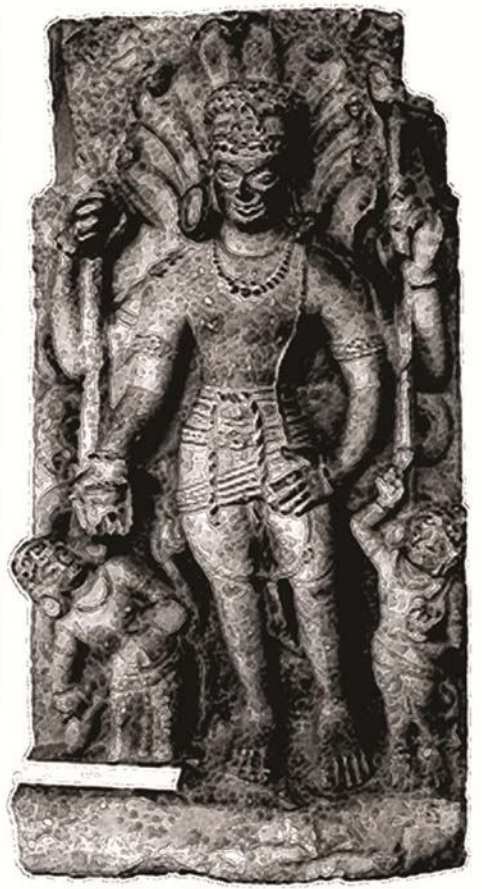

fig 3. Balarāma under a six-hooded canopy, stone-sculpture dated eighth-century AD, found from Paharpur, Bangladesh. [reference taken from Unknown. (Undated). Paharpur.

(http://en.banglapedia.org/index.php?title=Paharpur)]

During the era between eighth and twelfth century, ${ }^{42}$ a few more triad-images were manifested though the eleventh-century wooden derivation of Balarāma-Subhadrā-Jagannātha in Puri, Orissa, is completely different. ${ }^{43}$ Here, all the three deities were extraordinarily animated with gigantic heads, stump-like arms (except Subhadrā) and minimal bodies with no legs. Their iconography, style and structural execution appear to be closer to the localized genre of tribal idiom (see fig 4) rather than the usual renderings of contemporary Brahmanic genre. It is also the earliest available reference of Balarāma to be sculpted in wood.

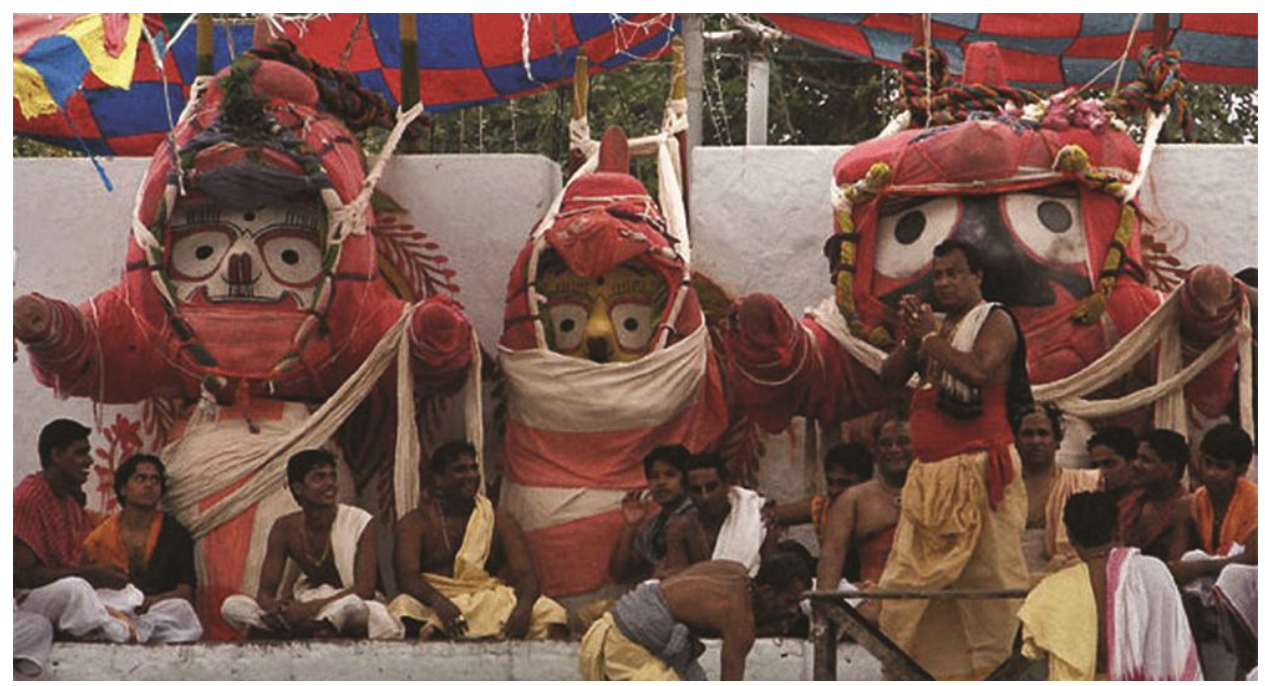

fig 4. Balarāma-Subhadrā-Jagannātha of Puri during Snānayātrā festival. 
By twelfth century AD, the Puri-triad gained its vitality and grace that gradually got spread through the other provinces of eastern India. ${ }^{44}$ Perhaps that is how, sometime in fourteenthcentury $\mathrm{AD},{ }^{45}$ the cult of Balarāma reached Boro - a small village in West Bengal. It might also be a renewed interest in Balaräma-worship that already had its root deep into this soil..$^{46}$ In any case, the colossal wooden deity is being worshipped today in a temple that is around fourteen-feet high (see fig 5) and appears to be built upon the debris of an older construction.

\section{Balarāma of Boro:}

It has been surmised that the eleven-foot Balarāma of Boro was originally installed sometime in fourteenth-fifteenth century AD. According to local legends, it was initiated by an old person whose boat was drowned while passing by a canal at the north-end of the village. He took refuge on a high land, where the Lord asked in his dream at night to be installed on that very spot. ${ }^{47}$ Since then, Balarāmajīu is being worshipped at Boro, whose familiarity was proclaimed by Mālādhara Basu in his fifteenth-century text of Śrīkrș̣na Vijaya. ${ }^{48}$

The present-day temple was built sometime in eighteenth or nineteenth century AD (see fig 6), while the main gate was erected much later in BS $1318 .{ }^{49}$ Even the wooden deity of today is a replica $^{50}$ of the original one ${ }^{51}$ - in the same medium - though the date of reproduction could not yet be finalized. However, its popularity has proudly been recorded in Dharma Mangala - an eighteenth-century text by Mānika Gaingopādhyāya..$^{52}$

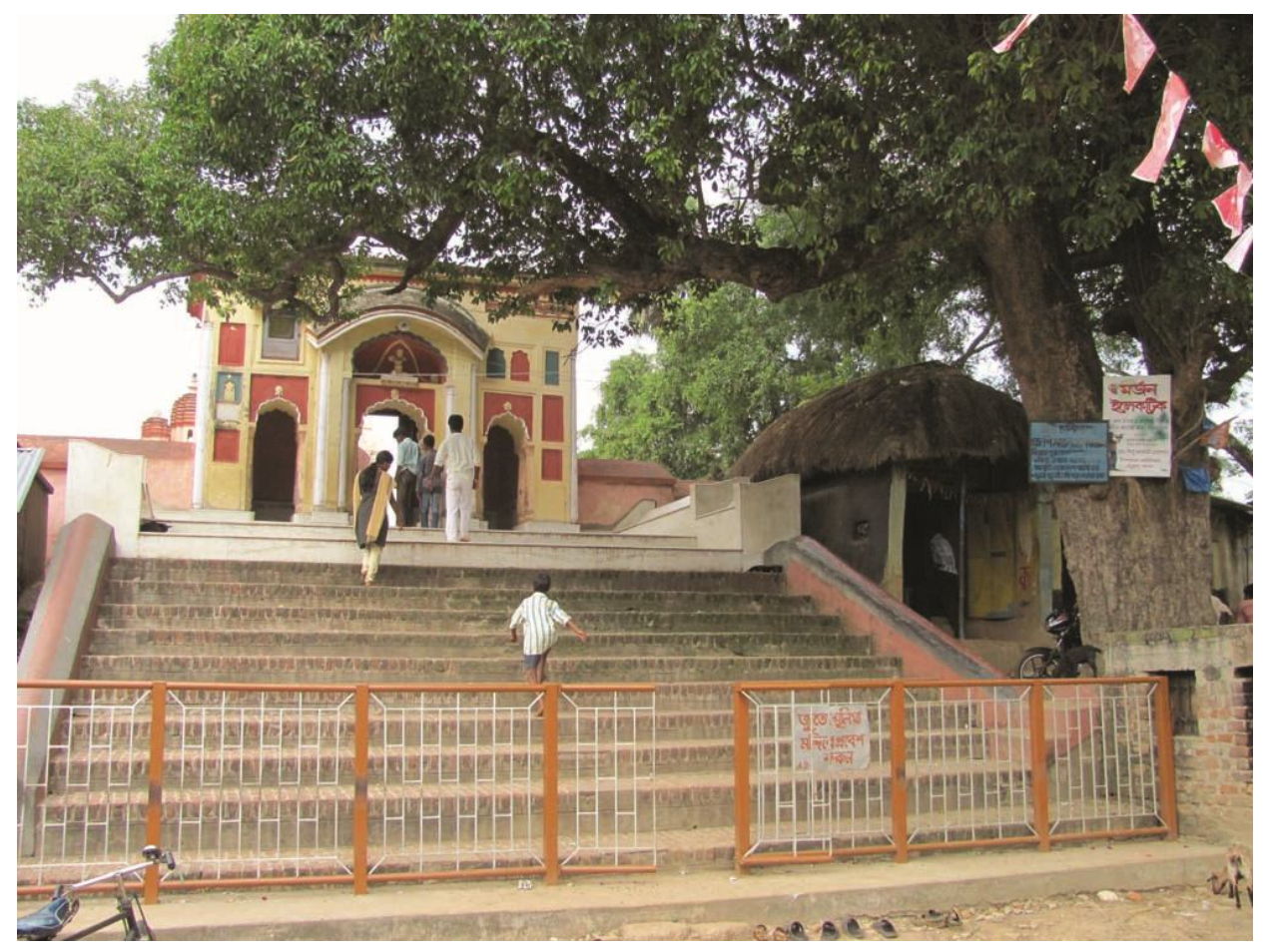

fig 5. Stairs leading towards the porch and the main entrance of Balarāma Temple at Boro.

\section{Uniqueness of Boro-Balarāma:}

Balarāma of Boro is unique with its iconography (see fig 7), which doesn't match with any description of the Purānas. None of the earlier manifestations have portrayed the Lord with such 
a heavy beard in particular and strong moustache. Even the canopy of thirteen-hooded serpent (see fig 8a) could not be traced in any of the previous renderings. ${ }^{53}$ Only the man-like torso and feminine abdomen (see fig 8b) are approved by narrations in Śrimad Bhāgavata ${ }^{54}$ and Caturvyūhatattva. $^{55}$

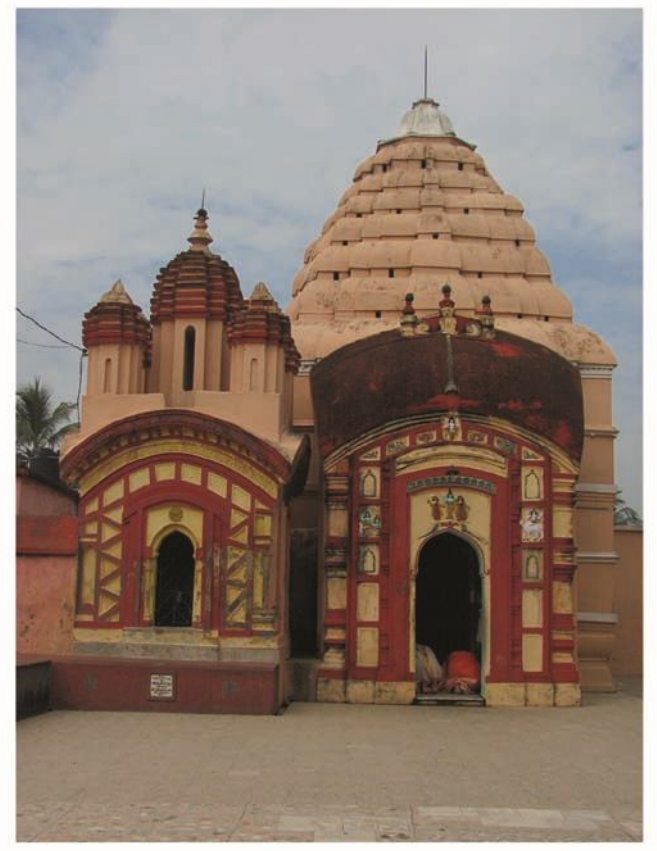

fig 6. The present-day Balarāma Temple at Boro, built in c. eighteenth or nineteenth century AD.

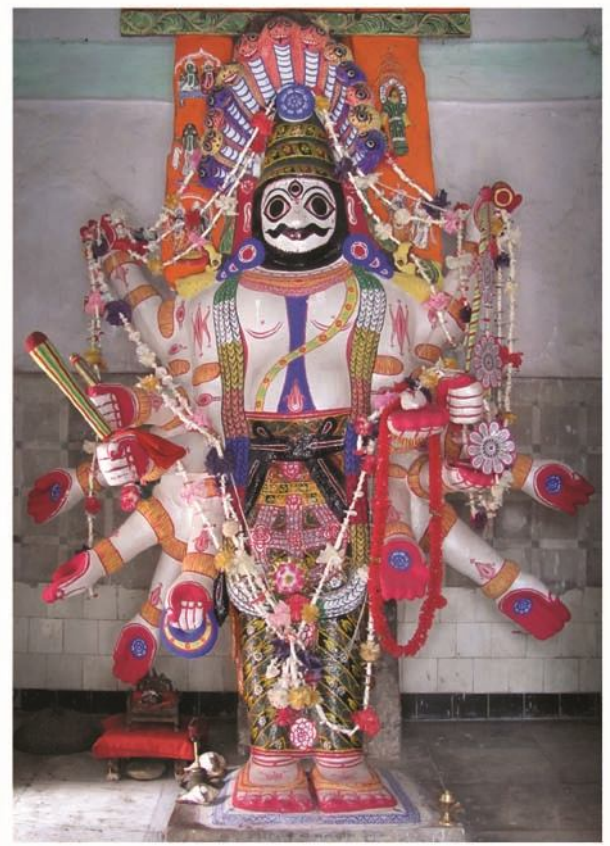

fig 7. The wooden idol of Balaräma at Boro; originally installed in c. fourteenth-fifteenth century AD.

In certain aspects, the icon of this Balaräma appears to be a rare combination of the two brothers - Sankkarșaṇa and Vāsudeva. Perhaps for this reason, he is having fourteen arms; as the former protects all the ten directions and the latter is prescribed with four. However, all these limbs are attached to his body with wooden bolts and nicely finished on the surface, resulting into a visual spectacle for the onlooker. The hands are holding attributes that are used by Ramacandra and Krṣna: like - Musala, ${ }^{56}$ mace, plough, conch-shell, Damaru, ${ }^{57} \mathrm{Cakra}^{58}$ and lotus. The rest are showing mudrā like Vara and Abhaya (see fig 8c \& 8d at page 82). ${ }^{59}$

In brief, it's a typical manifestation of Balarāma that represents the folk-tribal tradition of Bengal art. The massive scale and volume of the figure profoundly expresses great strength, vigor and vitality. Its shallow carving, gross details, blunt features, raw colors and bold patchworks - all these constitute a vibrancy, which is rarely found in the sophisticated renderings of hieratic genre. It is actually a venture of fourteenth-fifteenth century rural artisans - who were not so skilled and experienced in the making of wooden idols following the iconography of hieratic idiom. Eventual absence of the Pâla-Sena artists brought them an opportunity to apply their aesthetic perception, while exploring their traditional techniques on an apparently new medium.

Naturally, these newly appointed artisans were unable to carve the intrinsic and meticulous detail of the desired image. Hence, paint was introduced for depicting the facial features and other intricacies on the modest surface of simplistic carving. ${ }^{60}$ However, the resulting outcome was so popular that even the present-day replica has maintained the same formal appearance in every possible terms of aesthetic similitude. The crown, ornaments and basic dressmaterials have yet been carved on the surface, while the smaller motifs were executed with paintand-brush. The colour-scheme is based upon the white-complexion of the Lord, while the details 
are enriched with red, yellow, blue, green and black. Such a strong palate, along with the rounded eyes of the deity, reminds us of a stylistic similarity with the coloring-tradition of Orissan origin.

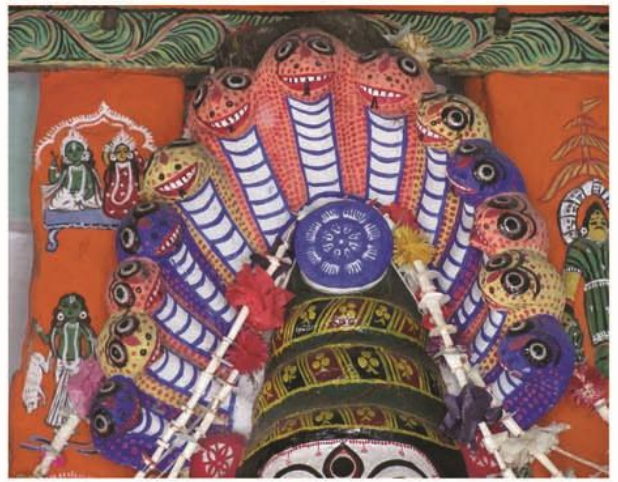

fig 8a. The thirteen-hooded Sarpa-chatra of Boro-Balaräma (detail)

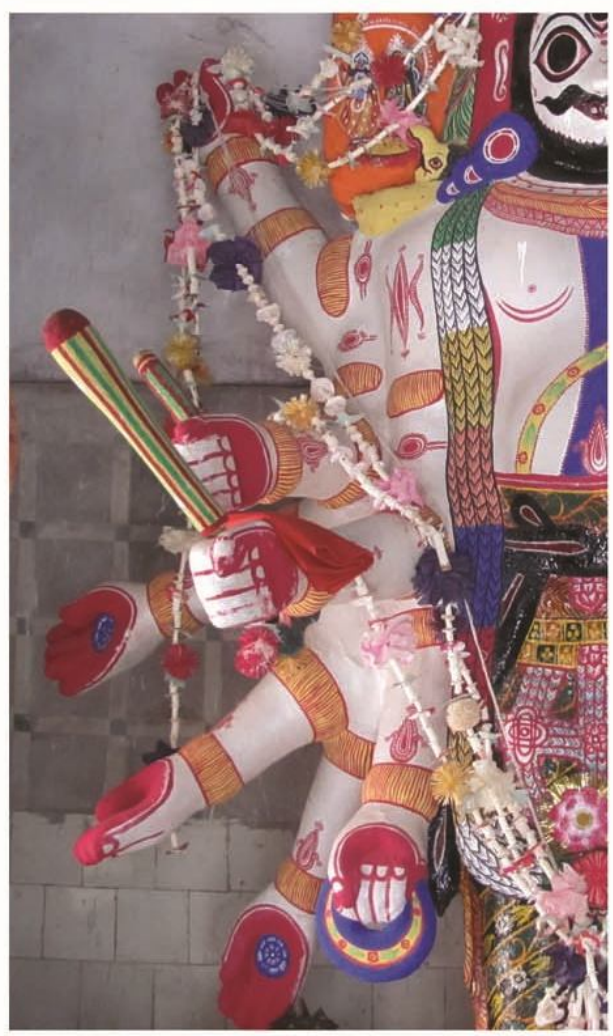

fig $8 \mathrm{c}$. The right hands and their attributes (detail).

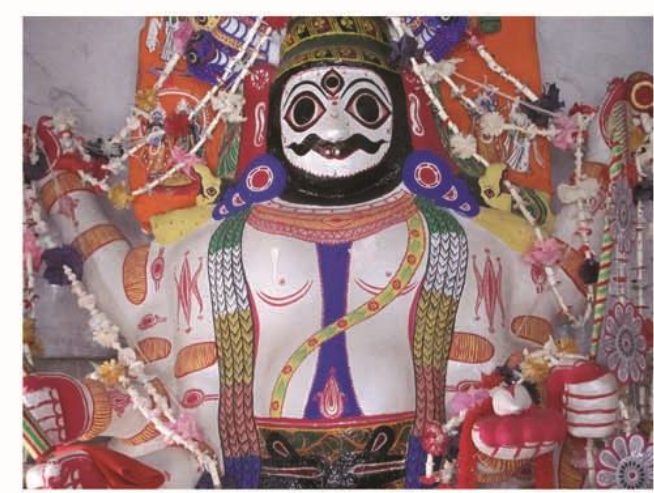

fig 8 b. The upper portion (detail).

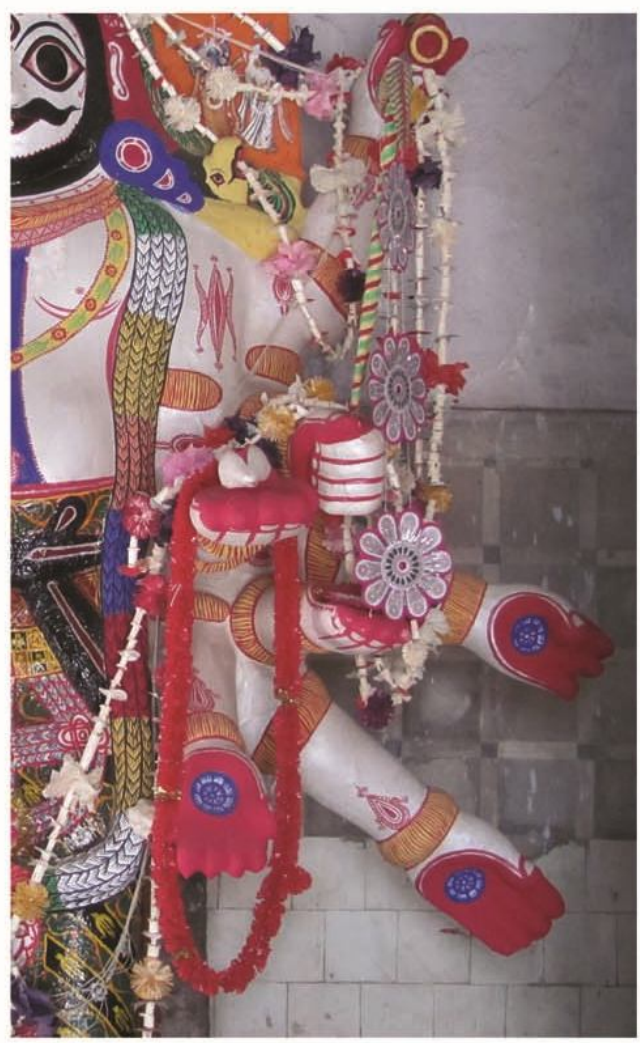

fig $8 \mathrm{~d}$. The left hands (detail).

\section{Epilogue:}

The divine images of pan-Indian idiom, including that of the Păla-Sena era, used to have large half-closed eyes ${ }^{61}$ - depicting a gesture of self-meditation. But the Balaräma of Boro as we see is looking up straight towards the devotee, making the eye-ball of the supreme fully visible. Although very common in folk-tribal idiom, it was a newly-introduced phenomenon in the hieratic level of Indian art. What was once private and restricted - kept far and away from the common people - thus became open and public, resulting into a major step towards religious 
democracy. Perhaps it was this shift in outlook, which has caused the Brahmanic icon of Balaräma to be worshipped as the God of rain and harvest in the regional traditions of Boro and its neighborhood.

For more than six hundred odd years, this idea, belief and devotion have profoundly been manifested in the collective consciousness of the local folk. In a larger context, such conceptual and aesthetic syntheses initiated the sculptural art of Bengal to liberate itself from the shackles of pan-Indian hegemony. Effort of this blending between the hieratic and the folk, general and local, is clearly evident in the few surviving specimens like Boro-Balarāma. Their fresh look and appearance thus represent a tradition - prevailing between thirteenth and fifteenth century AD that bears the markers of a future school of sculpture, purely of Bengal origin.

\section{Notes and References}

${ }^{1}$ Historically, the Muslims have been in India since the seventh century AD; but they came to the eastern provinces only at the end of twelfth. [see Bandyopadhyay, Rakhaldas. (BS 1324/1405). Bāngāāāra Itihāsa. Part II. Kolkata: Dey's Publishing. pp 4-5] The Sena-king fled away to the eastern provinces, where a small area was retained by the Dynasty - having Keśaba Sena as the last ruler (AD 1225-1230). Along with them, Deva Dynasty also ruled in that region for a brief period; while a few more indigenous kingdoms survived up to the 1450 in small pockets of eastern and southern Bengal. Finally, they surrendered before the Islamic might that was already established in their capital at Gaur. Only the Koch kingdom in the north could resist the Turk, Afghan and Mughal forces through the sixteen and seventeen centuries; and sustained up to the advent of the British.

${ }^{2} \mathrm{In} \mathrm{AD} 1203 / 04$.

${ }^{3}$ In the mean time, for a brief period, Gaur was ruled by the dynasties of South-Ganges, Nepal and Chandella. (see Bandyopadhyay, Rakhaldas: BS 1324/1405. Part II. p 12)

${ }^{4}$ Many such specimens of twelfth-thirteenth century AD - mostly of stone - are scattered today in a state of incompletion all over Bengal. For example, refer could be made of the Vișnu-image from Kumarpur, which is currently kept at the Varendra Research Museum at Rajshahi, Bangladesh (2006.01/92.99). The sculpture was stopped in the midway and left only with the rough-cuts.

${ }^{5}$ Their meticulous skill, which had remained a trademark of the Pāla-Sena school, now got employed in carving those intricate designs - both organic and geometric.

${ }^{6}$ Presumably this is one of the major reasons behind the development of a meticulous carving - that was typical to the Päla-Sena school - in the realm of Orissan sculpture during c. twelfth-thirteenth century AD.

${ }^{7}$ Perhaps, the Tripurāsundari of Boral in South 24 Parganas, West Bengal, was one of the last such efforts promoted by any royal family.

${ }^{8}$ For India, as a whole, it was a period of renewed scientific and technological contact with the outside world. The spinning wheel - probably a Chinese invention - came to India around this period only.

${ }^{9}$ see Sen, Dinesh Chandra. (1935/1999). Vṛhat Banga. Vol II. Kolkata: Dey’s Publishing. pp 649-674

${ }^{10}$ Eldest among the Kaurava-brothers, who were the sons of Dhṛtarāștra.

${ }^{11}$ Second of the Pāndava-brothers, who were the sons of Pāndu.

${ }^{12}$ The warrior-caste. 
${ }^{13}$ Ten incarnations: Hastī, Kūrma, Varāha, Nṛsimiha, Vāmana, Paraśurāma, Rāmacandra, Balarāma, Buddha and Kalki.

${ }^{14}$ The thought and imagination of Viṣnu, the preserver - also known as Viṣnu-Vāsudeva - was evolved and nourished from three different entities: Vedic sun-god Āditya-Viṣnu, cosmic-god Nārāyana (described in texts like Pañcavingśa-Śatapatha etc) and the man-god Vāsudeva-Kṛșna.

${ }^{15}$ Brahmā, Viṣnu and Maheśvara.

${ }^{16} \mathrm{Vol}$ V, ch 1, sūtra 59-63. The original text has variably been dated c. BC 700-300 / 400-300 / AD 275-325 / 1000 / ninth-century AD.

${ }^{17}$ see Donaldson, Thomas Eugene. (2001). The Iconography of Vaisnava Images in Orissa. New Delhi: D K Printworld (P) Ltd. pp 181-182

${ }^{18}$ In its primary level of emergence, Viṣnu-worshippers were not known as Vaiṣnava. Instead they used names like Bhāgavata, Sātvata, Ekāntika and Pañcarātrika. [see Dasgupta, Kalyan Kumar. (200o). Pratimāśilpe Hindu Devadevī. Kolkata: Paścimbañga Bāniglā Ākādemi. p 9]

${ }^{19}$ Eldest son of Kṛṣna and Rukminīi

${ }^{20}$ Son of Kṛșna and Jāmbavatī.

${ }^{21}$ Son of Pradyumna.

${ }^{22}$ i.e., five warriors.

${ }^{23}$ i.e. expansion.

${ }^{24}$ see Dasgupta, Kalyan Kumar: 2000. pp 36-37

${ }^{25}$ By c. second century BC, the final concept was formulated by including the theory of incarnation, while later in Gupta period the vyūhas increased to twenty four. (see Donaldson, Thomas Eugene: 2001. p 1)

${ }^{26}$ see Hopkins, Edward Washburn. (1915/1969). Epic Mythology with Additions and Corrections. New York: Biblo and Tannen. pp 63, 70, 102

${ }^{27}$ Book II, ch 26 , sūtra $48-58$. The text is believed to be a khila (i.e., appendix or supplement) to the Mahäbhärata and is traditionally ascribed to Veda Vyasa.

${ }^{28}$ see Dasgupta, Kalyan Kumar: 2000. pl 16

${ }^{29}$ c. $\mathrm{BC} 130-\mathrm{AD} 185$

${ }^{30}$ Acc. No: oo-C-15

${ }^{31}$ see Bhattacharya, Narendranath. (1993). Hooghly Jelāra Purākīrti. Kolkata: Pratnatattva Adhikār, Paścimbanga Sarakāra. p 117

${ }^{32}$ ch 58, sūtra 37 [see Unknown (tr). (1870/1875). The Brhat-Samhita (or complete system of natural astrology) of Varahamihira. Vol II. London. p 48].

${ }^{33}$ c. fourth-sixth century AD.

${ }^{34}$ Gwalior Museum.

35 The Patna Museum and The Archaeological Museum at Nalanda.

${ }^{36}$ Government Museum at Ajmer; and pillar of the seventh temple at Osian.

${ }^{37}$ Varendra Research Museum.

${ }^{38}$ On the temple-wall of Paharpur.

${ }^{39}$ see Chowdhury, Jajnesvar. (1994). Bardhaman: Itihāsa O Saṁskṛti. Vol III. Kolkata: Pustaka Bipaṇi. p 182 
${ }^{40}$ In the State Museum, Lucknow.

${ }^{41}$ From Imadpur of North Bihar.

${ }^{42}$ An eighth-century sculpture at Ellora in Maharashtra and a bronze-specimen at the British Museum, London are quite significant in this regard.

${ }^{43}$ It is one of the independent regional icons that took shape during c. AD 600-1200, while the iconography of Viṣnu-Vāsudeva passed through various changes. The central deity got split in this process and merged with various localized folk-tribal idioms. Other such derivations were Venkateśa of Tirupati in Andhra Pradesh, Vițthala-Viṭhoba, Pāndurañga, Dattātreya, Dhanvantarī, Vyasadeva and Annamūrti of Pandharpur in Maharashtra etc.

${ }^{44}$ The tradition reached Bengal towards the end of fifteenth-century and the Jagannätha-triad of Mahesh in Srirampur, Hooghly, appears to be the oldest one.

${ }^{45}$ see Dasgupta, Kalyan Kumar. (1990). Wood Carvings of Eastern India. Kolkata: Firma KLM Pvt Ltd. p 54

${ }^{46}$ Refer to the eighth-century specimen from Paharpur, Bangladesh.

${ }^{47}$ see Chowdhury, Jajnesvar: 1994. p 179

${ }^{48}$ see ibid

${ }^{49}$ By Nrisingha Basu in the memory of his parents Late Ramlal Basu and Late Rajkumari Dasi.

${ }^{50}$ Traditionally, in Bengal, any wooden idol once worn out is replaced by a similar replica. This act of replacement, if done with wood, is known as Navakalevara (i.e., the new body); while in certain cases, other mediums like clay, metal, stone etc were also used for the purpose. Perhaps the concept was borrowed from Orissa, where Navakalevara means the periodical renewal - usually on every eighth or eleventh or nineteenth year - of the wooden images of Sudarśana, Balabhadra, Subhadrā and Jagannātha in Puri.] In today's West Bengal, many such copied images are being worshipped in drastically restored or newly built temples.

${ }^{51}$ see Sen, Sukumar. (BS 1363, Bhādra-Āśvina). Boḍora Balarāma Vigraha. Paricaya, pp 4-5

${ }^{52}$ see Chowdhury, Jajnesvar: 1994. Vol III. p 179

${ }^{53}$ Some scholars have justified the canopy of thirteen-hooded serpent with the seven for Viṣnu-Vāsudeva and six for Sankarșana - considering the features of the Paharpur-specimen. (see Chowdhury, Jajnesvar: 1994. Vol III. p 182)

${ }^{54}$ see ibid, p 183

55 see ibid, p 182

${ }^{56}$ Pestle for husking rice; a mallet or hammer.

${ }^{57}$ Small drum or tabor.

${ }^{58}$ Discuss or wheel.

${ }^{59}$ Gestures showing boon and assurance.

${ }^{60}$ The folk-tribal artisans were always habituated in coloring their clay-sculptures with natural pigment. Hence, they were more comfortable with the use of paint rather than chisel-and-mallet.

${ }^{61}$ Matsyākr $r t i$ - i.e., the shape of a fish. 